\title{
KAJIAN RUANG DAN AKTIVITAS PASAR MINGGU TAMAN SETIABUDI BANYUMANIK TERHADAP TERBENTUKNYA KOHESI SOSIAL MASYARAKAT
}

\author{
Previari Umi Pramesti ${ }^{*}$, Bintang Noor Prabowo ${ }^{2}$, Muhammad Ismail Hasan $^{3}$ \\ *) Corresponding author email : previari_pramesti@yahoo.com \\ 1)Prodi Infrakstruktur Teknik Sipil dan Arsitektur, Sekolah Vokasi, Universitas Diponegoro - Indonesia \\ 2)Norges Teknisk Natuvitenskapnkapelige Universteit, Trondheim - Norway \\ Prodi Infrakstruktur Teknik Sipil dan Arsitektur, Sekolah Vokasi, Universitas Diponegoro - Indonesia \\ 3) Architecture Department, University of Malaya, Kuala Lumpur - Malaysia \\ Prodi Infrakstruktur Teknik Sipil dan Arsitektur, Sekolah Vokasi, Universitas Diponegoro - Indonesia
}

\begin{tabular}{l}
\hline Article info \\
MODUL vol 19 no 2, issues period 2019 \\
\hline Doi $\quad: 10.14710 /$ mdl.19.2.2019.110-118 \\
Received $:$ 10th october 2019 \\
Revised $:$ 3rd november 2019 \\
Accepted $:$ 15th november 2019
\end{tabular}

\begin{abstract}
ABSTRAKSI
Kohesi sosial adalah sebuah perekat yang secara fungsional merupakan kristalisasi dari adanya kesamaan famili, klan, etnik, kesamaan nasib, jenis pekerjaan, orientasi budaya, dan tujuan sosial. Dalam sudut pandang ini, terbentuknya sebuah masyatakat harus melalui mekanisme penyatuan berbagai kesamaan yang disebut di atas. Dengan kalimat lain, pembentukan sebuah masyarakat harus melalui mekanisme perekatan yang disebut kohesi sosial. Pasar Minggu Taman Setiabudi Banyumanik adalah salah satu fenomena sosial yang ada di wilayah Semarang Atas dimana terdapat aktivitas ekonomi yang secara tidak langsung memfasilitasi terciptanya aktivitas sosial masyarakat setempat. Analisis Teori Produksi Ruang Henri Lefebvre digunakan sebagai alat untuk membaca kondisi di lapangan.

Hasil penganalisaan diketahui bahwa kohesi sosial di Pasar Minggu Taman Setiabudi ini merupakan sinergi suatu interaksi dinamis antara proses sosial dan proses spasial, berupa tata ruang, perkembangan masyarakat urban, ruang publik, dan berbagai ekspresi budaya yang muncul atas berbagai praktek 'menghuni' suatu ruang.
\end{abstract}

Kata Kunci : Kohesi Sosial; Ruang Publik; kualitatif

\section{PENDAHULUAN}

Manusia sebagai makhluk sosial dalam kehidupannya mempunyai kebutuhan -kebutuhan, baik kebutuhan material maupun spiritual. Lingkungan hidup merupakan sarana di mana manusia berada sekaligus menyediakan kemungkinan - kemungkinan untuk dapat mengembangkan kebutuhan - kebutuhan. Oleh karena itu, antara manusia dengan lingkungan hidup terdapat hubungan yang saling mempengaruhi. Hubungan hubungan sosial yang terjadi secara dinamis yang menyangkut hubungan antara individu dengan individu, individu dengan kelompok, atau kelompok dengan kelompok dan berhubungan satu dengan yang lain disebut dengan interaksi sosial (Gillin dan Gillin,1954).

Interaksi sosial adalah syarat utama bagi terjadinya aktivitas sosial, kemudian akan membentuk suatu kenyataan sosial. Kenyataan sosial didasarkan pada motivasi individu dan tindakan - tindakan sosialnya. Ketika berinteraksi, seorang individu atau kelompok sosial pada dasarnya tengah berusaha untuk memahami tindakan sosial seorang individu atau kelompok sosial lain, perilaku sosial adalah hal yang dilakukan seorang individu atau kelompok sosial di dalam interaksi dan dalam situasi tertentu. Interaksi sosial bukan hanya memerlukan kemampuan untuk bertindak sesuai dengan konteks sosialnya, tetapi juga memerlukan kemampuan untuk menilai secara objektif perilaku pribadinya dipandang dari sudut sosial masyarakatnya (Narwoko, dalam Sampurna, 2013).

Masyarakat kota memiliki ciri-ciri yang khas yaitu cara hidup yang cenderung sekuler dengan berorientasi pada kehidupan duniawi yang dominan. Adapun perilaku individual masyarakat kota sangat dominan dengan pola interaksi yang didasarkan pada faktor kepentingan dari pada faktor pribadi atau komunal (Soekanto, 2001).

Kehidupan kota memiliki daya tarik yang cukup besar bagi masyarakat di daerah sekitarnya, karena masyarakat kota dianggap sebagai pusat perekonomian, sehingga masyarakat desa menganggap mudah mencari uang dan mudah mencari pekerjaan yang sesuai dengan 
pendidikannya. Selain itu, menurut Goede dalam (Ilhami : 1990) daya tarik kota yang lain adalah banyaknya fasilitas berupa sarana dan prasarana baik berupa fasilitas pendidikan, hiburan, transformasi, komunikasi maupun tempat-tempat rekreasi.

Komplek Perumahan adalah suatu bangunan perumahan yang dikelilingi oleh tembok di mana manusia tinggal didalamnya dan melangsungkan kehidupannya. Di samping itu, rumah juga merupakan tempat di mana berlangsung proses sosialisasi pada saat seorang individu diperkenalkan kepada norma dan adat kebiasaan yang berlaku di dalam suatu masyarakat, juga tempat individu untuk memenuhi kebutuhan-kebutuhan hidupnya.

Komplek perumahan yang umumnya dihuni masyarakat dari beragam latar belakang memaksa penghuninya untuk tetap menjaga jarak. Mereka tidak saling kenal sebelumnya sehingga belum saling percaya. Mereka sukar bertamu atau menerima tamu kecuali untuk keperluan tertentu. Desain perumahan yang minim membuat hubungan yang terbangun antar pemilik rumah hanya hubungan lahiriah karena mereka tinggal di tempat yang sama. Hubungan yang terjalin hanya konsekuensi logis dari persinggungan yang tidak disengaja. Sedangkan tradisi tegur sapa, senda gurau dan kerjasama tidak terbentuk karena mereka merasa mandiri secara ekonomi.

Fenomena tinggal di komplek perumahan juga memunculkan kekhawatiran terkait pergaulan antar penghuninya. Masyarakat yang tinggal di komplek perumahan sering kali terbatasi ruang interaksi sosialnya karena desain perumahan kurang mendukung, tentunya ini akan punya dampak besar terhadap rapuhnya struktur sosial masyarakat. Kerekatan sosial yang sejak ratusan tahun menjadi ciri khas bangsa Indonesia akan terkikis oleh proses sosial seperti ini. Masing-masing pemilik rumah tenggelam dalam keasyikan mengurus keperluan pribadi tanpa peduli urusan warga lain.

Hadirnya Pasar Minggu di Perumahan Taman Setiabudi Banyumanik Semarang menjadi angin segar bagi masyarakat perkotaan yang haus akan interaksi sosial antar warga. Hadir dalam konsep pasar tiban yang muncul dan tumbuh secara natural, Pasar Minggu ini menjadi wadah warga Banyumanik dan sekitarnya berekreasi di sela kesibukan dan penatnya rutinitas sehari-hari.

Tujuan penelitian ini adalah untuk mengetahui apakah keberadaan Pasar Minggu Taman Setiabudi di tengah-tengah komplek pemukiman warga ini mampu menfasilitasi warga untuk dapat beraktivitas sosial sehingga menumbuhkan kohesi sosial pada lingkungan tersebut.

Metode penelitian adalah deskriptif kualitatif yang menggunakan teori ruang publik dan teori produksi ruang Henri Lefebvre sebagai alat untuk melakukan analisis.

\section{KAJIAN PUSTAKA}

\section{Teori Kebutuhan (Needs)}

Abraham Maslow mengungkapkan teori kebutuhan yang menyebutkan bahwa tingkah laku individu berguna untuk memenuhi kebutuhannya, di mana teori ini mempunyai empat prinsip landasan, yakni

a. Manusia adalah binatang yang berkeinginan

b. Kebutuhan manusia tampak terorganisir dalam kebutuhan yang bertingkat - tingkat

c. Bila salah satu kebutuhan terpenuhi, kebutuhan lain akan muncul

d. Kebutuhan yang telah terpenuhi tidak mempunyai pengaruh, dan kebutuhan lain yang lebih tinggi menjadi dominan.

Dalam kebutuhan manusia, Abraham Maslow membagi menjadi lima macam kebutuhan manusia, yaitu :

a. Physical Needs (Kebutuhan-kebutuhan fisik)

Kebutuhan fisik merupakan kebutuhan yang berhubungan dengan kondisi tubuh seperti pangan, sandang, dan papan.

b. Safety Needs (Kebutuhan-kebutuhan rasa aman)

Kebutuhan ini lebih bersifat psikologi individu dalam kehidupan sehari-hari.

Misal : perlakuan adil, pengakuan hak dan kewajiban, jaminan keamanan.

c. Social Needs (Kebutuhan-kebutuhan sosial)

Kebutuhan ini juga cenderung bersifat psikologis dan sering kali berkaitan dengan kebutuhan lainnya. Misal: diakui sebagai anggota, diajak berpartisipasi, berkunjung ke tetangganya.

d. Esteem Needs (Kebutuhan - kebutuhan penghargaan) Kebutuhan ini menyangkut prestasi dan prestise individu setelah melakukan kegiatan. Misal : dihargai, dipuji, dipercaya.

e. Self Actualization (kebutuhan aktualisasi diri)

Kebutuhan ini merupakan kebutuhan tertinggi dari individu dan kebutuhan ini sekaligus paling sulit dilaksanakan. Misal : mengakui pendapat orang lain, mengakui kebenaran orang lain, mengakui kesalahan orang lain,dapat menyesuaikan diri dengan situasi.

Dari Kebutuhan (Needs) menurut Murray dapat dikelompokkan menjadi tiga kategori, yaitu:

a. Sikap Kerja, yang meliputi :

Need of endurance, change, Achievement, order, Autonomy.

b. Sikap Sosial, yang meliputi :

Need of Affiliation, Intraception, Abasement, Deference, Nurturence, Succorance, Dominance, Heterosexsual. 
c. Sikap Diri, yang meliputi :

Need of Exhibition, Aggression.

Dalam pembahasan ini, lebih ditekankan pada Social Needs dan kelompok kategori Sikap Sosial khususnya AFFILIATION (AFF) yaitu kebutuhan untuk bersekutu dengan orang lain, menggambarkan :

a. Kesetian kepada teman

b. Butuh kehadiran orang lain

c. Suka berpartisipasi pada kelompok

d. Suka berbuat untuk orang lain

e. Suka membentuk keterikatan interpersonal

f. Kemauan untuk melakukan partisipasi social

\section{Teori Ruang Publik}

Secara sederhana, yang dimaksud ruang publik adalah ruang yang dapat dimanfaatkan oleh masyarakat umum sepanjang waktu, tanpa dipungut bayaran (Danisworo dalam Sampurno, 2013). Baskoro Tedjo dalam Sampurna (2013) mendefinisikan ruang publik sebagai ruang yang netral dan terbuka untuk siapa saja, untuk berkegiatan dan berinteraksi sosial. Ruang publik membutuhkan kebersamaan terbuka (publicness) sebagai prasyarat, yang pada gilirannya membutuhkan suatu tingkat kesetaraan paling tidak dalam hal kesejahteraan ekonomi (Kusumawijaya, 2004). Ruang sebagai wadah harus mampu menyediakan lingkungan yang kondusif bagi terpenuhinya syarat interaksi, yaitu memberi peluang bagi terjadinya kontak dan komunikasi antar warga. Aktivitas sosial dapat diartikan sebagai kegiatan yang membutuhkan kehadiran orang lain (Zhang dan Lawson, 2009). Kegiatan ini dapat berupa perbincangan santai di pinggir jalan, bertatap muka maupun anak-anak bermain di taman. Aspek - aspek yang mempengaruhi lingkungan dalam penggunaan lahan :

a. Orang melakukan aktivitas "bersama"

Komponen "bersama" hasilnya mencakup interaksi pengguna ruang yang menggambarkan siklus hidup, karakter etnis ataupun regional. Pengguna ruang yang terlibat dalam komponen tersebut memerlukan ruang dan periode waktu dalam aktivitasnya. Selain itu "bersama" termasuk di dalamnya adalah masyarakat yang keberadaannya memberikan faktor positif walaupun tidak melakukan interaksi. Ruang yang membuat pengguna ruang datang dan ingin memanfaatkannya karena adanya aktivitas yang dilakukan masyarakat.

b. Pengaturan aktivitas

Ketentuan mengenai aktivitas dan penggunaan ruang diatur oleh masyarakat itu sendiri. Pengaturan tersebut ditentukan dari aspek fisik lingkungan seperti lokasi dan karakteristik tempatnya. Pengaturan aktivitas meliputi faktor yang membentuk satu kesatuan yang dibutuhkan dalam lokasi, seperti ukuran dan jumlah, keterbukaan, dominasi microclimate, kesesuaian terhadap aktivitas lain, keberagaman dan pemakaian alat. Terdapat perbedaan ruang dalam penggunaannya, yaitu ruang fixed dan adaptable. Ruang fixed memberikan batasan terhadap pengguna dan harus sesuai dengan aktivitas yang menaunginya. Ruang adaptable dapat menyesuaikan aktivitas sesuai kebutuhan.

c. Keterkaitan dengan alam lingkungan

Keterkaitan dengan alam merupakan salah satu aspek pemanfaatan lingkungan yang terpenting. Keterkaitan melibatkan rasa kekeluargaan yang erat dengan alam dan identitas diri menjadi bagian dari alam yang menjadi kesinambungan yang dinamis.

d. Aman

Dalam memanfaatkan ruang, orang cenderung memilih berdasarkan faktor keamanan. Aspek keamanan mengandung dimensi fisik dan sosial. Keamanan fisik termasuk fasilitas yang digunakan dalam suatu tempat sebagai alat bantu aktivitas untuk perlindungan terhadap situasi yang berbahaya dan special setting seperti penghalang dan tanda. Keamanan sosial dapat dilakukan dengan pengawasan dan program kegiatan. Konflik dapat terjadi dari beragamnya pengguna, proses interaksi sosial dalam hal wilayah, dominasi, serta interaksi dan beragam aktivitas.

e. Estetika

Keindahan berdasarkan oleh taste atau style. Aspek keindahan yang lain terdapat dalam kesatuan visual, yang terdiri dari kebersihan, kesan menyeluruh, pendorong keseimbangan dan keserasian sekuen. Kesan menyeluruh diperoleh dari ruang, warna, bentuk dan tekstur secara lengkap dalam keserasian dan keseimbangan. Keserasian sekuen diperoleh dari gaya 3D yang linier saat masyarakat melihat.

f. Kemudahan

Pertimbangan utama kemudahan adalah jarak.Jarak berguna dalam waktu, moda transportasi,dan dapat menggambarkan kondisi nyata dan fungsional. Jarak yang nyata merupakan pengukuran dengan menggunakan dimensi atau satuan ukuran, sedangkan jarak fungsional merupakan pengukuran hubungan yang menjadi fokus lingkungan atau pola lingkungan. Jarak yang nyata juga mempertimbangkan waktu, kenyamanan dan biaya transport.

g. Kenyamanan psikologis

Terdapat 3 indikator kenyamanan psikologis, yaitu mengeluarkan emosi, penguatan sosial, dan seimbang antara pilihan yang muda dan tua. Pengeluaran emosi merupakan wujud tingkah laku yang agresif, sehingga memerlukan lingkungan yang memuaskan emosinya. Penguatan sosial membuat masyarakat merasa aman, dicintai dan diperhatikan. Menyeimbangkan pilihan antara yang muda dan tua 
dengan pemberian pengalaman baru dan pilihan yang aman.

h. Kenyamanan fisik

Kenyamanan fisik melibatkan faktor lokasi dan fasilitas yang mengabungkan kenyamanan sosial dan ruang yang berdaya guna.

Faktor lokasi terdiri dari cuaca (terpenting), lokasi microclimate dan polusi. Kenyamanan fisik yang lain adalah fasilitas yang memadai dengan moda transportasi dan keamanan fisik serta perlengkapan yang menjadi dasar kebutuhan psikologis.

i. Kepemilikan simbolis

Kepemilikan simbolis akan meningkatkan penggunaan ruang. Indikator dari kepemilikan simbolis adalah saat seseorang menggunakan ruang dan penggunanya semakin bertambah maka akan terjadi pengakuan terhadap suatu ruang, saat terdapat barang milik seseorang dalam suatu tempat, saat hukum kepemilikan menjadi tidak jelas, saat ruang diakui secara pribadi oleh pengguna, dan saat seseorang tinggal dekat dengan suatu tempat.

j. Kebijakan penggunaan

Kebijakan penggunaan dapat diketahui melalui sebuah tanda. Pengaturan penggunaan lingkungan memungkinkan kebijakan atas ijin dan mendorong adanya kegiatan serta membatasi kebijakan yang melarang adanya kegiatan.

k. Biaya

Prinsip biaya dalam penggunaan ruang adalah semakin murah semakin bagus. Biaya terdiri dari transportasi dan pengisian untuk fasilitas. Biaya dianggap minor, karena dalam lingkungan orang lebih memilih berjalan kaki sehingga tidak mengeluarkan uang. Biaya mayor lebih menekankan pada konstruksi dan membesarkan penggunaan lahan.

\section{Teori Produksi Ruang Henry Lefebvre}

Tindakan sosial membentuk ruang sosial, baik secara individual maupun secara kolektif. Tindakan sosial memberi "makna" pada cara suatu ruang spasial dikonsepsikan oleh mereka yang mengisi dan menghidupkan ruang tersebut. Produksi ruang sosial berkaitan dengan bagaimana praktik spasial diwujudkan melalui persepsi atas lingkungan (environment) yang dibangun melalui jaringan (networks) yang mengaitkan aktivitas-aktivitas sosial seperti pekerjaan, kehidupan pribadi (private life), dan waktu luang (leisure). Lefebvre mendeskripsikan itu sebagai hubungan yang bersifat dialektis antara ruang (spasial dan sosial) yang hidup, ruang yang dipersepsikan, dan ruang yang dikonsepsikan, atau apa yang disebut sebagai "tiga rangkaian konseptual atas ruang" (a conceptual triad of social space production). Adalah pemahaman yang komprehensif tentang cara kerja tiga rangkaian konseptual atas produksi ruang sosial itu yang juga menjadi bagian penting dari reproduksi pengetahuan yang bersifat ideologis bagi perkembangan suatu kota.

Tiga rangkaian konseptual atas ruang yang dimaksud Lefebvre menjelaskan bagaimana suatu ruang sosial dihasilkan, yaitu sebagai berikut :

(1) Praktik Spasial (Spatial Practices).

Praktik spasial mengacu pada produksi dan reproduksi hubungan spasial antar objek dan produk. Hal inilah yang turut menjamin berlangsungnya kontinuitas produksi ruang sosial dan kohesivitasnya. Dalam pengertian ini, ruang sosial meliputi pula keterlibatan setiap anggota masyarakat yang memiliki hubungan atau keterkaitan tertentu terhadap kepemilikan atas ruang itu. Dengan demikian, kohesi sosial atas suatu ruang ditentukan oleh derajat kompetensi dan tingkat kinerja atas pemakaian ruang (fisik atau material). Praktik spasial semacam inilah yang dipahami sebagai "ruang yang hidup" (lived space).

(2)Representasi Ruang (Representations of Space). Representasi ruang tergantung pada pola hubungan produksi dan tatanan yang bertujuan memaksakan suatu pola hubungan tertentu atas "pemakaian" suatu ruang. Maka, representasi ruang berkenaan dengan pengetahuan, tanda-tanda, atau kode-kode, bahkan sikap atau suatu hubungan yang bersifat "frontal".

Representasi - representasi yang dihasilkan oleh suatu ruang oleh karena itu menjadi "beragam". Representasi - representasi semacam itu merujuk pada suatu ruang yang "dikonsepsikan", seperti dari para seniman yang memiliki ekspresi dan sikap mental misalnya yang unik dalam mengidentifikasi "ruang" - sementara para pengkaji memandang proses pembentukan atas ruang sebagai suatu rekayasa ilmiah - seperti melalui kajian (studi) atau penelitian dengan cara mengidentifikasi apa saja yang menghidupi suatu ruang, konsekuensi apa yang dirasakan oleh orang atas "ruang" itu serta apa yang mereka pahami tentang ruang tersebut dan dinamikanya. Pada konteks inilah ruang merupakan suatu produksi yang muncul dari konsepsi orang dan/atau beberapa orang atau orang pada umumnya; "ruang" yang dikonsepsikan (conceived space).

(3).Ruang Representasional (Representational Space)

Ruang representational mengacu pada ruang yang secara nyata "hidup" (lived space) dan berkaitan secara langsung dengan berbagai bentuk pencitraan serta simbol yang terkait dengannya. Hal ini termasuk bagaimana para penghuni ruang atau orang-orang yang menggunakannya saling berinteraksi melalui praktik dan bentuk visualisasi di dalam suatu ruang. Konsepsi atas ruang pun muncul berdasarkan berbagai pengalaman nyata yang dialami oleh setiap orang sebagai sebab - akibat dari 
suatu hubungan yang bersifat dialektis antara praktik spasial dan representasi ruang. Ruang menjadi sesuatu yang secara khusus dipersepsikan oleh individu, kelompok, atau suatu masyarakat; ruang yang dipersepsikan (perceived space).

\section{Teori Kohesi Sosial}

Secara etimologi kohesi merupakan kemampuan suatu kelompok untuk menyatu, dan kohesi sosial merupakan hasil dari hubungan individu dan lembaga. Pengertian mengenai konsep kohesi sosial yang asli sendiri berasal dari tesis Emile Durkheim. Menurutnya terdapat solidaritas mekanik yang diindikasikan dengan adanya pelaku-pelaku yang kuat dalam masyarakat, lalu terdapat solidaritas organik yang diindikasikan dengan saling bergantungnya individu maka akan terbentuk suatu kohesi sosial dengan sendirinya. Definisi lainnya didasarkan kepada keterikatan masyarakat yang terbentuk dengan sendirinya dan bukan hasil dari pemahaman untuk mencapai kohesi sosial. Lalu terdapat definisi yang didasari oleh persamaan nilai dan rasa memiliki, menjelaskan bahwa kohesi sosial tercipta karena persamaan nilai, persamaan tantangan dan kesempatan yang setara didasari oleh harapan dan kepercayaan. Pengertian atau definisi yang terakhir didasari oleh kemampuan untuk bekerja bersama dalam suatu entitas yang akan menghasilkan kohesi sosial.

Secara tipologis, kohesi sosial dapat dikategorikan secara kasar ke dalam dua tipe, yaitu kohesi sosial intramasyarakat dan kohesi social antarmasyarakat. Kohesi sosial intramasyarakat secara historis terbentuk melalui suatu mekanisme perbentukan sosio-kultur dalam suatu masyarakat tunggal ( single society).

Masyarakat tunggal lazimnya menempati satu wilayah mukim atau beberapa wilayah mukim tetapi memelihara tata adab dan tata sosial yang sama. Tata adab dan tata tata sosial yang sama itu menjadi panduan berinteraksi. Dalam masyarakat tunggal tertentu,perekatan ini juga ditentukan oleh jenis pekerjaan atau mata pencaharian yang dominan seperti petani atau nelayan.

a. Kohesi sosial antarmasyarakat secara historis terbentuk melalui pertemuan sosial secara lintas masyarakat. Pertemuan sosial itu terbentuk oleh adanya saling butuh, kemudian membentuk suatu mekanisme sosial saling membantu. kohesi sosial antarmasyarakat terbentuk lebih pada mekanisme pragmatis-ekonomis. Secara teologis-kultural, kohesi sosial antarmasyarakat mungkin dibentuk oleh semangat pertetanggaan dan saling bantu yang diolah dari sumber-sumber tata adab mengenai etika berkoeksistensi dan persamaan makhluk ciptaan Tuhan yang diambil dari teks-teks keagamaan. b. Kohesi sosial intramasyarakat terbentuk melalui mekanisme interaksi sosial dalam satu masyarakat tunggal yang didorong oleh kesadaran kekerabatan,

\section{KONDISI DAN ANALISIS OBJEK}

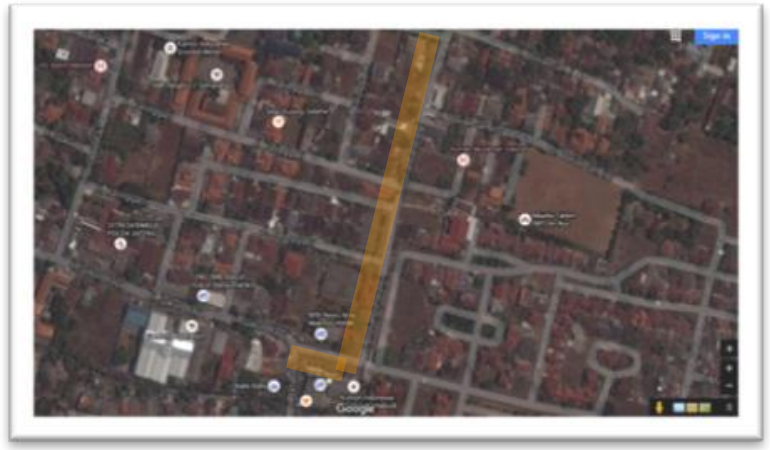

Gambar 1. Peta Taman Setiabudi dan Jalan Durian Selatan II (Sumber : Google Maps, 2016)

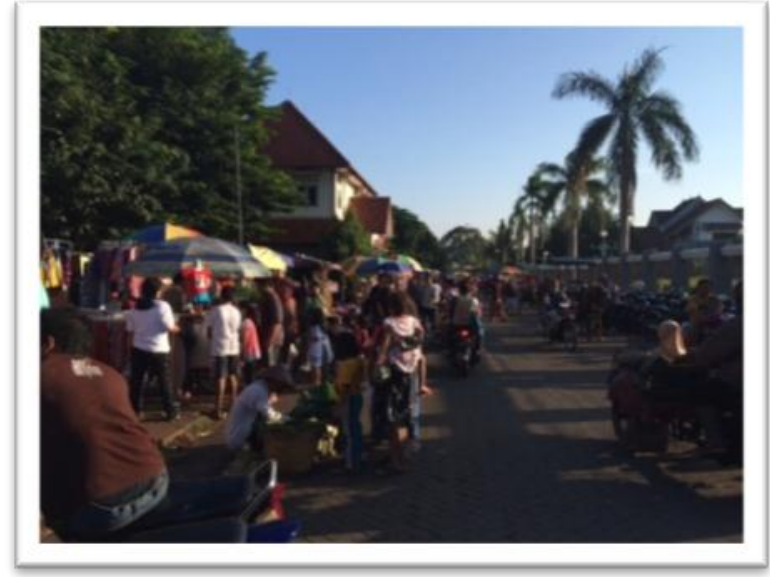

Gambar 2. Suasana Pasar Minggu Taman Setiabudi (Sumber : Penulis, 2016)

Pasar Minggu Pagi Taman Setiabudi Banyumanik Semarang yang telah ada pada kurun 2 tahun terakhir ini menjadi salah satu fenomena baru di masyarakat Banyumanik dan sekitarnya. Pasar Minggu ini memanfaatkan penggal jalan lingkungan antara Perumahan Taman Setiabudi yang melewati Jalan Durian Selatan hingga menuju Jalan Durian Raya. Munculnya Pasar Minggu ini seolah menjadi magnet warga Banyumanik untuk datang dan beraktivitas di hari libur mereka. PKL yang pada awalnya hanya berada di depan Perumahan Taman Setiabudi, saat ini terus bertambah hingga hampir memenuhi seluruh penggal jalan lingkungan tersebut. Pasar Minggu ini menjadi wadah interaksi dan sosialisasi masyarakat di daerah tersebut.

\section{Analisis terhadap Teori Kebutuhan}

Berdasarkan Teori Kebutuhan (Needs) menurut Abraham Maslow yaitu manusia memiliki kebutuhan Sosial (Sosial Needs) yang bersifat psikologis dan menurut Murray tentang kebutuhan Sikap Sosial 
Manusia, yang salah satunya yaitu Affiliation. Masyarakat pada umumnya memiliki sifat dasar seperti membutuhkan kehadiran orang lain, suka berpartisipasi pada kelompok, suka membentuk keterikatan interpersonal, adanya kemauan untuk melakukan partisipasi sosial, dan tidak suka menyendiri. Hal tersebut dapat difasilitasi dengan adanya ruang untuk berinteraksi dan melakukan aktivitas sosial dengan manusia lain seperti melakukan sosialisasi serta aktualisasi diri. Dalam hal ini, Pasar Minggu Pagi Taman Setiabudi menjadi salah satu ruang yang dapat menfasilitasi kebutuhan manusia akan Sosial Needs tersebut.

\section{Analisis terhadap Teori Ruang Publik}

Sesuai dengan definisi Ruang Publik menurut Danisworo (2004), penggal jalan Taman SetiabudiDurian Raya ini benar-benar dimanfaatkan oleh masyarakat umum tanpa dipungut biaya, adapun biaya yang dibebankan setahun terakhir ini kepada para PKL semata untuk menertibkan para PKL agar lebih bertanggung jawab atas masing-masing lapak mereka. Adapun Baskoro Tedjo (2005) mendefinisikan ruang publik sebagai ruang yang netral dan terbuka untuk siapa saja, untuk berkegiatan dan berinteraksi sosial, berdasarkan pengamatan dan wawancara dengan beberapa responden Pasar Minggu ini tidak membatasi siapapun yang datang baik penjual maupun pembeli, tidak terbatas masyarakat Banyumanik saja. Bahkan mayoritas penjual justru dari luar wilayah Banyumanik. Penggunaan Penggal Jalan Lingkungan untuk Pasar Minggu ini secara tidak langsung membentuk ruang publik bagi masyarakat. Ruang publik ini menyediakan segala kesempatan bagi setiap lapisan masyarakat untuk saling mengenal, mengamati apa dan bagaimana suatu masyarakat berkembang. Di ruang publik ini hampir tak ada batasan kelas sosial yang mencolok - meskipun penanda kelas sosial tetaplah hadir di dalam ruang publik.Adapun kemudian ruang publik yang terbentuk secara natural ini menjadi wadah terciptanya aktivitas sosial antar masyarakat. (Zhang dan Lawson, 2009)

Jalan yang dijadikan sebagai tempat jual beli dapat memperpanjang aktivitas untuk jalan sekunder atau tempat tersebut menjadi ruang terbuka antara beberapa jalan ${ }^{8}$. Aktivitas sosial - ekonomi sangat berperan penting terhadap kehidupan kota yang dapat diukur melalui jumlah penduduk, perputaran uang, aktivitas - aktivitas ekonomi, jumlah jenis organisasi atau lembaga formal maupun nonformal.

$$
\text { Berdasarkan Aspek Lingkungan dalam }
$$

Penggunaan Lahan

a. Orang melakukan aktivitas "bersama"

Pengguna ruang yang teribat dalam ruang komponen tersebut memerlukan ruang dan periode tertentu.Kegiatan Pasar Minggu Taman Setiabudi ini menggunakan penggal jalan Taman Setiabudi Durian Selatan sebagai "ruang" berkegiatan dan dalam periode waktu pukul 05.00-12.00.

Aktivitas utama masyarakat yang terlibat dalam Pasar Minggu ini adalah transaksi jual beli/perdagangan termasuk persewaan dokar dan odong-odong. Selain itu, terdapat beberapa aktivitas komunitas seperti komunitas sepeda, komunitas lansia, komunitas tenis yang berkumpul di spot-spot tertentu.

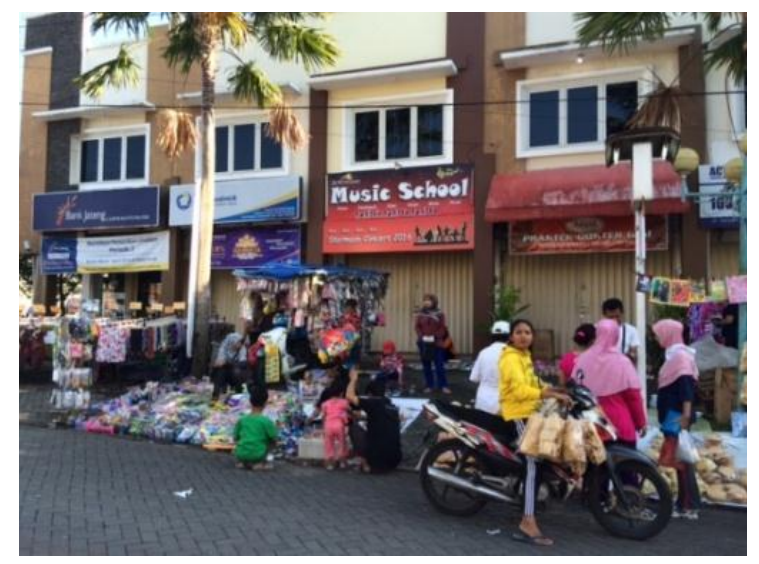

Gambar 3. Aktivitas Jual Beli (Sumber : Penulis, 2016)

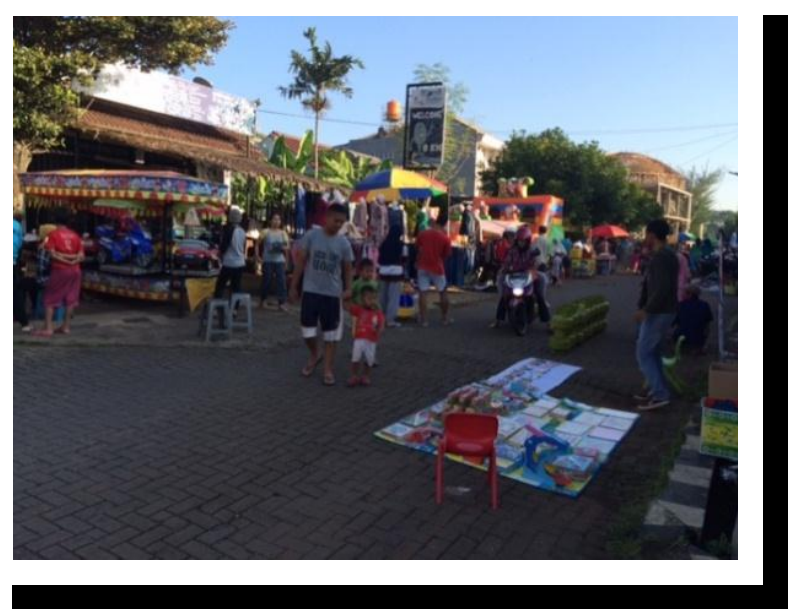

Gambar 4. Aktivitas Permainan Anak

(Sumber : Penulis, 2016)

b. Pengaturan aktivitas

Ruang yang terbentuk di Pasar Minggu Taman Setiabudi ini dapat digolongkan sebagai Ruang Adaptable, dimana ruang dapat menyesuaikan aktivitas dan kebutuhan. Salah satu poin positif dari ruang terbuka publik yang digunakan Pasar Minggu ini adalah aktivitasnya tidak dibatasi oleh ruang masif/fixed. Aktivitas di dalamnya-pun beragam dan masih berpotensi untuk dieksplorasi.

c. Keterkaitan dengan alam lingkungan Penggal jalan yang digunakan untuk Pasar Minggu 
ini adalah penggal jalan yang menghubungkan antara kompleks perumahan satu dengan lainnya. Dalam hal ini lingkungan dalam konteks alami sudah tidak mendominasi, bahkan nyaris sudah tidak ada vegetasi di area tersebut. Hanya ada beberapa pohon dan tanaman di titik-titik tertentu. Banyaknya PKL di lokasi tersebut menyebabkan penggunaan lahan yang sempit pun dimanfaatkan sedemikian rupa termasuk membuka lapak di bawah pohon.

d. Aman

Tidak dapat dipungkiri keamanan sosial menjadi hal yang diharapkan masyarakat untuk beraktivitas dengan nyaman tanpa rasa was-was. Penggal jalan yang sempit dan penuh dengan PKL serta lalu lalang orang menimbulkan kerawanan akan kriminalitas seperti copet. Selain itu, walaupun penggal jalan ini digunakan untuk kegiatan Pasar Minggu, namun lalu lalang mobil, motor dan dokar tetap melintas di area tersebut. Hal ini berpotensi menimbulkan kecelakaan, tidak hanya saja bagi pengunjung tapi juga penjual (PKL).

Khususnya PKL, hingga saat ini belum ada asuransi yang mencover apabila terjadi kecelakaan pada saat berjualan di Pasar Minggu, namun menurut salah satu pengelola Pasar Minggu ini, sedang diupayakan memperoleh asuransi bagi para PKL yang menjamin keselamatan mereka saat berjualan.Sehingga ada jaminan / rasa aman bagi para PKL dalam berjualan.

e. Estetika

Estetika merupakan salah satu aspek yang bersifat subjektif.Namun dapat digeneralisasikan bahwa masyarakat pada umumnya menyukai sesuatu yang bersih, rapi dan indah dan teratur secara visual.Pasar Minggu ini terdiri dari banyak PKL dengan berbagai macam barang dan karakteristik penjual.Ada yang mengggunakan tenda, meja, gerobak, bagasi mobil, bahkan hanya beralaskan tikar untuk berjualan. Parkiran motor yang ada di sela-sela PKL menambah komposisi Pasar Minggu ini. Hal tersebut tidak menjadi masalah apabila dapat dilakukan penataan yang estetis, karena justru heterogenitas ini yang menjadi salah satu poin menarik dari Pasar Minggu ini. Keberagaman ini akan semakin indah apabila didukung dengan kebersihan dan tata kelola sampah yang baik.

Salah satu hal yang disayangkan dari kegiatan di area ini adalah adanya dokar yang seringkali mengabaikan kotoran kuda yang terjatuh di area Pasar Minggu.Dalam hal ini, diperlukan peraturan yang mengatur keberadaan dokar di area tersebut.

f. Kemudahan

Saat ini Pasar Minggu Taman Setiabudi menjadi salah satu icon besar di Banyumanik.Lokasi menjadi salah satu daya tarik bagi masyarakat, dimana posisinya strategis dan mudah diakses dari berbagai arah (dari Sukun, dari Jati, dari Durian Raya). Bagi masyarakat yag bertempat tinggal di Taman Setiabudi, Durian Selatan, Jati dan Sukun dapat dengan mudah diakses dengan berjalan kaki atau kendaraan umum. Bagi yang membawa motor, kemudahan untuk memarkir motor dengan aman dan nyaman tersedia di Pasar Minggu ini.

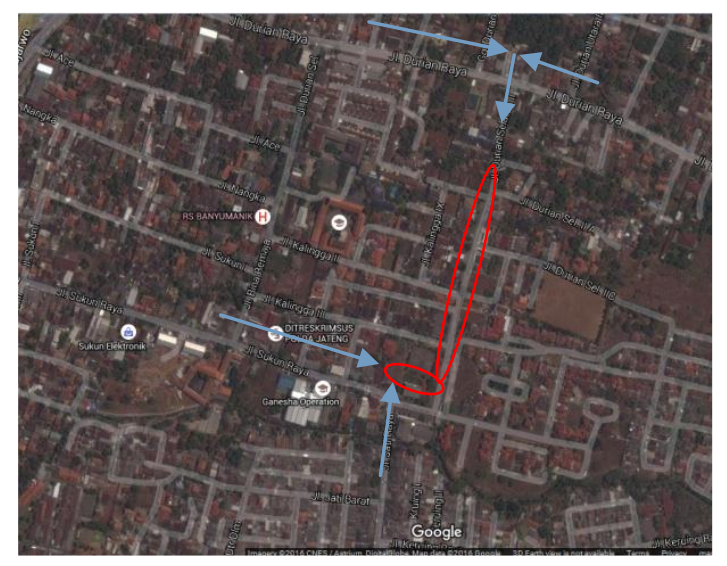

Gambar 5. Kemudahan Akses

(Sumber : Analisis Penulis, 2016)

g. Kenyamanan Psikologis

Ramainya Pasar Minggu Taman Setiabudi serta kurangnya vegetasi pelindung di area tersebut membuat kurangnya kenyamanan psikologis bagi para pengunjung. Ditambah lagi dengan kendaraan yang masih berlalu lalang di dalam pasar minggu ini, membuat ketidaknyamanan bagi pengunjung maupun PKL.

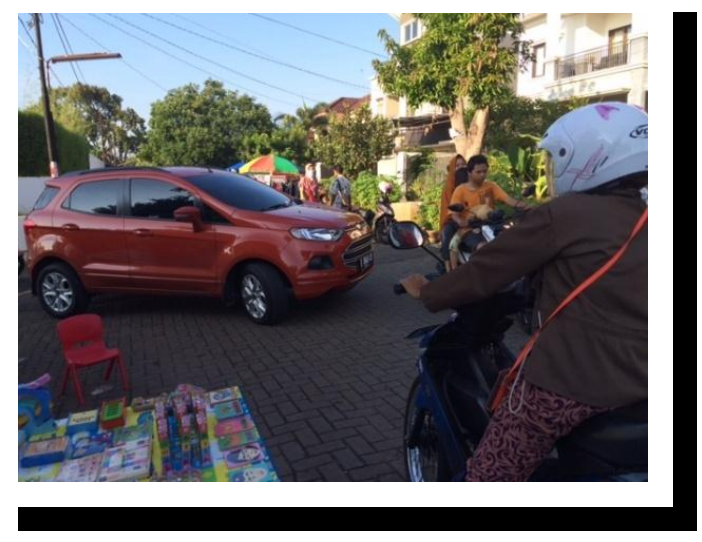

Gambar 6. Lalu Lalang Kendaraan di Dalam Area Pasar Minggu

h. Kenyamanan Fisik

Faktor terpenting dari aspek kenyamanan fisik ini adalah cuaca / climate. Lokasi Pasar minggu yang menggunakan penggal jalan serta berada dikelilingi oleh jalan - jalan raya sangat rentan akan polusi 
udara. Minimnya vegetasi pelindung membuat kenyamanan fisik pengunjung berkurang ketika hari menjelang siang.Ditambah pula dengan sampah basah dan kotoran kuda yang menimbulkan bau apabila tidak ditatakelola dengan baik.

i. Kepemilikan Simbolis

Saat ini dapat dikatakan Pasar Minggu Taman Setiabudi ini adalah milik warga Banyumanik secara simbolik.Dimana keberadaan Pasar Minggu ini menjadi moment yang ditunggu-tunggu masyarakat setuap minggunya dan menjadi magnet bagi pengunjung baik dari Banyumanik sendiri maupun dari luar Banyumanik.

j. Kebijakan Penggunaan

Sejauh ini adanya Pasar Minggu Taman Setiabudi masih menggunakan kebijakan setempat, yaitu ijin dari RT/RW yang memiliki penggal jalan tersebut. Tentu saja kegiatan ini mendapat ijin dan penduduk pemukiman di sekitarnya, karena pada saat pasar ini beroperasi terdapat beberapa rumah penduduk yang tertutupi atau bahkan digunakan untuk berkegiatan baik berjualan maupun parkir. Sampai saat ini organisasi Pasar Minggu ini dikelola oleh perwakilan RT/RW setempat.

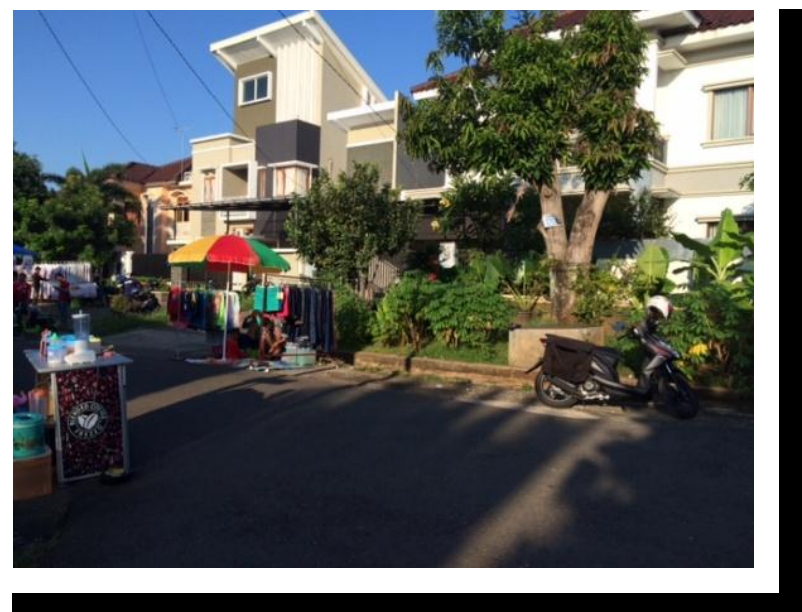

Gambar 7. PKL di Depan Rumah Warga

(Sumber : Penulis, 2016)

k. Biaya

Bagi pengunjung, khususnya warga Banyumanik dan sekitarnya, biaya yang dikeluarkan untuk mengakses pasar minggu ini terbilang murah atau bahkan costless (di luar konteks mereka berbelanja atau makan). Jika hanya ingin berjalan-jalan, berolahraga dan beraktivitas sosial, pasar minggu ini menjadi wahana yang murah-meriah sekaligus menghibur.

\section{Analisis berdasarkan Teori Henry Lefebvre dikaitkan dengan Teori Kohesi Sosial}

Faktor utama terbentuknya kohesi sosial melalui ruang terbuka publik adalah karakteristik ruang terbuka publik yang inklusif, dapat dimasuki oleh orang lintas etnis, status sosial-ekonomi. Hal yang penting dari penjelasan Peters et al. (2010) adalah bahwa kohesi sosial terstimulasi tidak harus dengan interaksi sosial yang intensif, formal, dan terstruktur dengan orang atau kelompok yang sudah dikenal, melainkan dapat dimulai dengan interaksi sosial yang bersifat informal dan sepintas lalu (cursory), misalnya mengobrol singkat, atau melalui sapaan "halo". Seperti aktivitas sosial yang terjalin secara natural di Pasar Minggu Taman Setiabudi, didominasi interaksi sosial yang bersifat informal dan sepintas lalu.Hal tersebut dapat disebabkan oleh kegiatan pasar minggu mayoritas jual beli dan persewaan.Bahkan di lokasi ini, pengunjung bisa berjumpa dengan tetangga mereka yang kemungkinan jarang bertemu di lingkungan tempat tinggal mereka sendiri.

Untuk menjadikan ruang publik benar-benar bermanfaat adalah dengan memperhatikan fungsi dan kepadatan di sekitarnya.Seperti halnya Pasar Minggu Taman Setiabudi ini, ruang terbuka umum idealnya memang berada di tengah kawasan padat sehingga semakin banyak pula warga yang bisa mengakses dan memanfaatkannya. Melalui interaksi sosial yang diakomodasi dalam ruang publik terjadi pembelajaran antara manusia satu dengan manusia lainnya, komunitas satu dengan komunitas lain. Proses ini berlangsung terus menerus sehingga menanamkan kesadaran warga untuk menerima konsekuensi hidup berkota yaitu heterogenitas yang tinggi. Dengan interaksi yang terjalin mesra maka kohesi sosial akan terbangun. Arnberger dan Eder (2012) memaknai kohesi sosial sebagai kelekatan komunitas.

Menurut Habermas, ruang publik tak mensyaratkan orang untuk memiliki status sosial tertentu atau kekhususan yang mengenal hierarki sehingga keberadaannya menjadi sangat penting bagi suatu komunikasi politik - antar warga masyarakat sendiri maupun dengan pemerintah. Begitupula dengan pengunjung dan partisipan Pasar Minggu ini datang dari berbagai macam strata sosial dan ekonomi yang membaur tanpa ada pembatas-pembatas yang mengkotak-kotakan aktivitas mereka di lingkungan tersebut.

Sementara, Henry Lefebvre menilai bahwa ruang publik bukanlah suatu ruang alternatif - ruang publik adalah kebutuhan yang tak terhindari bagi berlangsungnya kohesivitas sosial. Lefebvre juga menilai bahwa kebutuhan ruang publik bukan hanya penting dan mendesak bagi keberlangsungan kohesi sosial, Betapa tidak?Masyarakat masa kini cenderung malas beraktivitas sosial secara formal. Justru dengan munculnya Pasar Minggu Taman Setiabudi ini menjadi ruang publik yang menfasilitasi keberlangsungan kohesi sosial. Dalam konteks ini ruang publik merupakan ruang 
pertemuan bagi banyak orang dimana setiap orang memiliki kepentingannya masing-masing, akan tetapi tidak dapat secara individual mengklaim kepemilikan mereka atas ruang itu. Ruang publik lebih merupakan ruang relaksasi yang membuat setiap orang menjauhkan kepentingan individualnya masing-masing dan bertemu untuk memperoleh ketenangan dari kebisingan dan beban hidup sehari-hari.

Ruang publik dapat pula memfasilitasi keberadaan berbagai macam komunitas yang beragam di dalam masyarakat. Seperti halnya di Pasar Minggu ini beberapa komunitas berkumpul untuk aktualisasi diri seperti komunitas sepeda, komunitas lansia, dan beberapa komunitas pemuda.

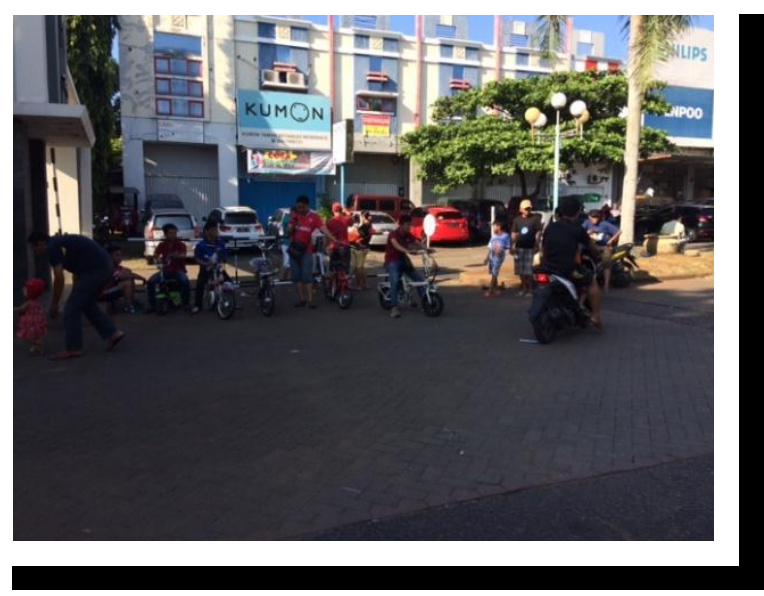

Gambar 8. Komunitas Sepeda (Sumber : Penulis, 2016)

\section{KESIMPULAN}

Dari uraian analisis di atas, dapat disimpulkan bahwa kohesi sosial di Pasar Minggu Taman Setiabudi ini merupakan sinergi suatu interaksi dinamis antara proses sosial dan proses spasial, misalnya tata ruang, perkembangan masyarakat urban, ruang publik, dan berbagai ekspresi budaya yang muncul atas berbagai praktek 'menghuni' suatu ruang.

Melalui interaksi sosial yang demikian, orangorang merasa disambut, terhubung (connected) dengan warga rumah, dan sekaligus merasa seperti di rumah (feel at home). Ruang terbuka publik yang berfungsi seperti ini menarik ragam orang, dalam hal mana pengalaman sehari-hari terbagi dan ternegosiasikan di antara orang-orang.Selanjutnya, tumbuh "kesadaran ruang publik" (public space consciousness) terhadap ruang terbuka publik itu sendiri, di mana ruang publik diapresiasi karena memiliki nilai dan fungsional merangsang dan menciptakan perasaan nyaman, keakraban serta kerekatan dengan warga atau publik.

Kohesi sosial yang terbentuk dalam kegiatan Pasar Minggu Taman Setiabudi Banyumanik ini juga mencakup perasaan kebersamaan (sense of belonging), kepercayaan sosial (social trust), dan kerjasama timbal balik (generalised reciprocity and cooperation), serta keharmonisan sosial (social harmony).

\section{DAFTAR PUSTAKA}

Arnberger dan Eder (2012) The influence of the green space on community attachment of urban and suburban residents, urban forestry and greening 11 (1) p41-49

Gillin dan Gillin (1954) Cultural Sociology, Newyork : The Mc Millian co

Hester. R.T., (1984). Planning Neighborhood Space with People. USA: Van Nostrand Reinhold Company

Ilhami (1990) Strategi Pembangunan Perkotaan di Indonesia, Usaha Nasional : Surabaya

Johnson, Doyle Paul (1988). Teori Sosiologi Klasik dan Modern. Jakarta : Gramedia

Kostof, Spiro (1992). The City Assembled The Elements of Urban Form Through History. London:Thames and Hudson Narwoko

Kusumawijaya, Marco (2004) Jakarta Metropolis Tunggang Langgang, Gagas Media, Jakarta

Lefebvre, Henry (1991) The production of space english translation, Blackwell : England

Maslow, Abraham (1943) Theory of Human Motivation Physchological review (50) p 370-396

Rahaju, Soerjanti \& Nur Apriyanti (2008).Diktat Asesmen Kepribadian EPPS-SSCT-Pauli. Surabaya: UNESA

Ritzer, George. (2012, cetakan ke-8). Teori Sosiologi "Dari Sosiologi Klasik Sampai Perkembangan Terakhir Postmodern”.Yogyakarta : Pustaka Pelajar

Robet, Robertus (2014). Ruang Sebagai Produksi Sosial Dalam Henri Lefebvre. Jakarta : Kompasiana.

Sampurna, Bisma Putra (2013).Memahami Konsep Kohesi Sosial.Jakarta : Kompasiana.

Santoso, Slamet (2010).Teori-Teori Psikologi Sosial Bandung: Refika Aditama.

Soekanto (2001) Hukum Adat Indonesia, PT. Raja Grafindo Persada : Jakarta

Zhang dan Lawson, 2009, Meeting and Greeting : Activities in public outdoor spaces outside high density urban resindential communities, Urban Design International 14 (4) p 207-214 